\title{
Trichoderma-Enriched Biofertilizer Enhances Production and Nutritional Quality of Tomato (Lycopersicon esculentum Mill.) and Minimizes NPK Fertilizer Use
}

\author{
Abul Hossain Molla $\cdot$ Md. Manjurul Haque • \\ Md. Amdadul Haque • G. N. M. Ilias
}

Received: 2 March 2012 / Accepted: 14 June 2012/Published online: 5 July 2012

(C) NAAS (National Academy of Agricultural Sciences) 2012

\begin{abstract}
Effective biofertilizer reduces not only the load of chemical fertilizers in crop production but also minimizes the pollution by excessive uses of the latter. The impact of Trichoderma-enriched biofertilizer (BioF), i.e., BioF/compost (household/kitchen wastes composted by Trichoderma harzianum T22) and BioF/liquid (T. harzianum T22 grown in liquid media, i.e., broth culture) were evaluated to recognize their roles in growth, yield and nutritional quality of tomato (Lycopersicon esculentum Mill.) in field studies. Encouraging responses were monitored in all respects. Above 200 and $336.5 \%$ yield increase were recorded over control by BioF/compost alone $\left(\mathrm{T}_{3}\right)$ and its combination with N:P:K (Nitrogen:Phosphorus:Potassium) application $\left(\mathrm{T}_{4}\right)$, respectively. Application of $50 \% \mathrm{BioF} /$ compost and $50 \% \mathrm{BioF} / \mathrm{liquid}$ with $50 \% \mathrm{~N}: \mathrm{P}: \mathrm{K}$, provided statistically similar and significant $(P \leq 0.05)$ performance over control but not significant with standard dose of N:P:K. Total soluble solids, sugar, ascorbic acid, $\beta$-carotene, lycopene, phosphorus and manganese content in tomato were significantly higher when fertilized with BioF/compost. In addition, protein content and some essential minerals were increased in $50 \%$ BioF/compost $+50 \% \mathrm{~N}: \mathrm{P}: \mathrm{K}$ treatment. Trichoderma composted kitchen wastes can serve as prospective biofertilizer for improvement in yield and quality of tomato cultivation.
\end{abstract}

Keywords Biofertilizer $\cdot$ Trichoderma harzianum T22 $\cdot$ Kitchen waste $\cdot$ N:P:K use $\cdot$ Yield $\cdot$ Nutritional quality $\cdot$ Tomato

A. H. Molla $(\bowtie) \cdot$ Md. Manjurul Haque

Department of Bioenvironmental Science,

Faculty of Agriculture, Bangabandhu Sheikh Mujibur Rahman

Agricultural University, Gazipur 1706, Bangladesh

e-mail: ahmolla60@gmail.com; ahmolla@bsmrau.edu.bd

Md. Manjurul Haque

e-mail: haque59@hotmail.com

Md. Amdadul Haque

Department of Agro-processing, Bangabandhu Sheikh Mujibur

Rahman Agricultural University, Gazipur 1706, Bangladesh

e-mail: amdadhstu@yahoo.com

G. N. M. Ilias

Natore Development Society (NDS), Natore and M/S RASH

Agro Enterprise, Natore 6400, Bangladesh

e-mail: gnmilias@yahoo.com

\section{Introduction}

Tomato (Lycopersicon esculentum Mill.) is one of the most popular vegetables worldwide, and contains carbohydrates, amino acids, minerals, and vitamins. Yield and nutrient content of tomato are dramatically affected by the application of inorganic fertilizer [13]. In fact, non-judicious use of inorganic fertilizer may lead to environmental pollution including contamination of groundwater, and soil acidification as well as increase denitrification resulting in higher the emission of nitrous oxide $\left(\mathrm{N}_{2} \mathrm{O}\right)$ to the atmosphere which is responsible for global warming. Currents efforts include exploring the possibility of substitution of inorganic fertilizer with organic ones which are eco-friendly and cost effective. Taiwo et al. [33] suggested that organic fertilizer 
can be combined with inorganic fertilizer at rates below those recommended for sustainable tomato production. Yield of tomato are significantly lower in organically fertilized plants than the plants that receiving inorganic fertilizer [16]. In recent years, biofertilizer, products containing living cells of different types of microorganisms have emerged as an important component in integrated nutrient supply system and hold a great promise to improve yield and quality of crop through better nutrient supplies [39].

Trichoderma, a filamentous fungus is opportunistic, avirulent symbionts that are used as biopesticide, biofertilizer or fertility promoter worldwide [14, 15, 34]. Application of Trichoderma may result in the promotion of plant growth, yield and increase nutrient availability [4, 5, 9, 10, 15, 34, 42, 43]. In addition, several species of Trichoderma are wellknown producers of different kinds of secondary metabolites [29] that are important for plant growth regulation [34, 36, 37]. Some Trichoderma strains may also be able to colonize root surfaces and cause substantial changes in plant metabolism [15]. Furthermore, Trichoderma may produce organic acids that decrease soil $\mathrm{pH}$ and permit the solubilization of phosphates, micronutrients and mineral cations like iron, manganese, and magnesium that are useful for plant metabolism [8]. Molecular study revealed that Trichoderma metabolites or roots colonization by Trichoderma, changes the proteome and transcriptome of plants [1, 23, 31].

The effect of Trichoderma on plant growth and productivity has been studied for a large number of plant species mainly in greenhouse or in pot experiments. However, very little attention has been paid to the combined use of Trichoderma-enriched biofertilizer and chemical fertilizer on growth, yield attributes, yield and nutritional quality of crops under field conditions. Efficient use of Trichoderma-enriched biofertilizer alone or in combination with chemical fertilizer may increase yield and quality of tomato, reduce the load of $\mathrm{N}: \mathrm{P}: \mathrm{K}$ use and associated environmental pollution. Thus, this study was undertaken to evaluate the impact of Trichoderma-enriched biofertilizer such as BioF/compost (household/kitchen wastes composted with Trichoderma harzianum T22) and BioF/liquid (broth culture containing spores and mycelia of T. harzianum T22) alone or in combination with chemical (N:P:K) fertilizer on growth, yield attributes, yield and nutritional quality of tomato as well as screening the best dose and combination for sustainable tomato production.

\section{Materials and Methods}

Experimental Site and Weather Condition

A field experiment was carried out during November 2009 to March 2010 at agricultural research farm of
Table 1 Physico-chemical characteristics of the soil in the experimental site

\begin{tabular}{ll}
\hline Physical characteristics & \\
Textural class & Silty clay loam to clay loam \\
Bulk density $(\mathrm{g} / \mathrm{cc})$ & 1.33 \\
Particle density $(\mathrm{g} / \mathrm{cc})$ & 2.61 \\
Porosity $(\%)$ & 46.9 \\
Chemical characteristics & \\
$\mathrm{pH}$ & 6.1 \\
Organic carbon $(\%)$ & 0.75 \\
Organic matter $(\%)$ & 1.12 \\
Total N ( \%) & 0.091 \\
Available P $(\mu \mathrm{g} / \mathrm{g})$ & 16.0 \\
Exchangeable K $(\mathrm{meq} / 100 \mathrm{~g})$ & 0.32 \\
\hline
\end{tabular}

Bangabandhu Sheikh Mujibur Rahman Agricultural University (BSMRAU), Gazipur, Bangladesh. The GPS (Global Positioning System) of experimental site is at $24.09^{\circ} \mathrm{N}$ latitude and $90.26^{\circ} \mathrm{E}$ longitude with an elevation of 8.4 meter above the mean seal level. Soil of the experimental site is belonging to the Salna series representing the Shallow Red Brown Terrace Soil which falls under the order of inceptisols and agro-ecological zone (AEZ) of Madhupur Tract (AEZ 28). The physicochemical properties of the soil in the experimental site including initial N:P:K status was shown in Table 1. In the experimental area, the minimum and maximum air temperature varied between $11-27$ and $14-34{ }^{\circ} \mathrm{C}$, soil temperature in 10-, 20-, and 30-cm depth varied between $16-27.5,16.5-28$, and $17-28.5^{\circ} \mathrm{C}$, respectively; ground water table varied between 15.60 and $18.56 \mathrm{~m}$ and total amount of rainfall was $2.92 \mathrm{~mm}$ during the entire cropping period.

\section{Raising Seedlings, Transplantation, and Crop Management}

Seeds of tomato, variety Bangladesh Agricultural Research Institute (BARI) 14 were collected from the Horticulture Centre of BARI, Gazipur, Bangladesh. Seedlings were grown in seed bed and 30 days old, uniform healthy seedlings were transplanted on 15 November 2009 as one seedling per pit. The unit plot size was $2.5 \mathrm{~m} \times 2.0 \mathrm{~m}$ and spacing was $50 \mathrm{~cm} \times 50 \mathrm{~cm}$. The intercultural operations viz. gap filling, weeding, stalking, pruning, irrigation, etc. were done as per standard management practice.

\section{Requirements of N:P:K and Biofertilizers}

For higher yield of tomato, the required amount of N:P:K [as source of urea, triple super phosphate (TSP) and 
Table 2 Soil test interpretation (STVI) class and the respective recommended fertilizer nutrients [6]

\begin{tabular}{|c|c|c|c|c|c|c|}
\hline \multirow[t]{2}{*}{ STVI class } & \multicolumn{3}{|c|}{ Limit of the soil test value within the STVI class } & \multicolumn{3}{|c|}{ Fertilizer recommendation of the respective STVI class $(\mathrm{kg} / \mathrm{ha})$} \\
\hline & $\mathrm{N}(\%)$ & $\mathrm{P}(\mu \mathrm{g} / \mathrm{g})$ & $\mathrm{K}(\mathrm{meq} / 100 \mathrm{~g})$ & $\mathrm{N}$ & $\mathrm{P}$ & $\mathrm{K}$ \\
\hline Very low & $<0.09$ & $<7.5$ & $<0.09$ & $121-160$ & $37-48$ & $76-100$ \\
\hline Low & 0.091 & $7.51-15.0$ & 0.091 & $81-120$ & $25-36$ & $51-75$ \\
\hline Medium & $0.181-0.27$ & $15.1-22.5$ & $0.181-0.27$ & $41-80$ & $13-24$ & $26-50$ \\
\hline Optimum & $0.271-0.36$ & $22.51-30$ & $0.271-0.36$ & $0-40$ & $0-12$ & $0-25$ \\
\hline High & $0.361-0.45$ & $30.1-37.5$ & $0.361-0.45$ & - & - & - \\
\hline Very high & $>0.45$ & $>37.5$ & $>0.45$ & - & - & - \\
\hline
\end{tabular}

muriate of potash (MOP), respectively] were calculated based on following equation of Bangladesh Agricultural Research Council (BARC) 2005 [6]:

$\mathrm{Fr}=\mathrm{Uf}-\mathrm{Ci} / \mathrm{Cs} \times(\mathrm{St}-\mathrm{Ls})$,

where Fr is the fertilizer nutrient required for given soil test value, Uf is the upper limit of the recommended fertilizer nutrient for the respective soil test interpretation (STVI) class, $\mathrm{Ci}$ is the units of class intervals used for fertilizer nutrient recommendation, $\mathrm{Cs}$ is the units of class intervals used for STVI class, St is the soil test value, and Ls is the lower limit of the soil test value within STVI class (Table 2). The required amount of N:P:K for a $5-\mathrm{m}^{2}$ plot (g) were 60:54:5, respectively.

Trichoderma harzianum T22-enriched biofertilizers such as BioF/compost and BioF/liquid were collected from Natore Development Society (NDS) and M/S RASH Agro Enterprise, Natore, Bangladesh. BioF/compost and BioF/liquid were applied at the rate of $680 \mathrm{~g} / \mathrm{plot}$ and $5 \mathrm{ml} / \mathrm{plant}$, respectively, as recommended by the producers. The N:P:K content of BioF/compost were 1.63:0.142:1.35\%, respectively. Moreover, the microbial status of T. harzianum T22 in BioF/compost and BioF/liquid was $7.92 \times 10^{3} \mathrm{cfu} / \mathrm{g}$ and $11.90 \times 10^{6} \mathrm{cfu} / \mathrm{ml}$, respectively. However, the broth media of BioF/liquid contained ( $\mathrm{g} / \mathrm{l}) \mathrm{KNO}_{3}$ 1.0, $\mathrm{KH}_{2} \mathrm{PO}_{4} 0.5$, $\mathrm{MgSO}_{4} \cdot 7 \mathrm{H}_{2} \mathrm{O} 0.25$, glucose 34 , trace amount $\mathrm{FeCl}_{3} 0.25-0.50$ were dissolved in distilled water and $\mathrm{pH} 6.5$ was maintained.

\section{Experimental Design and Treatments}

The experiment was conducted in a randomized complete block design (RCBD) with five replications and eight treatments. The treatments were: (i) $\mathrm{T}_{1}$ - control (without BioF and $\mathrm{N}: \mathrm{P}: \mathrm{K}$ ), (ii) $\mathrm{T}_{2}$-recommended dose of $\mathrm{N}: \mathrm{P}: \mathrm{K}$ (120:108:10 $\mathrm{kg} \mathrm{ha}^{-1}$ ), (iii) $\mathrm{T}_{3}-\mathrm{BioF} /$ compost (household/ kitchen wastes composted with $T$. harzianum T22), (iv) $\mathrm{T}_{4}-50 \%$ BioF/compost $+50 \% \mathrm{~N}: \mathrm{P}: \mathrm{K},(\mathrm{v}) \mathrm{T}_{5}-75 \%$ BioF/compost $+25 \% \mathrm{~N}: \mathrm{P}: \mathrm{K}$, (vi) $\mathrm{T}_{6}-\mathrm{BioF} /$ liquid (broth containing spores and mycelia of $T$. harzianum $\mathrm{T} 22$ grown in liquid media), (vii) $\mathrm{T}_{7}-50 \%$ BioF/liquid $+50 \%$ $\mathrm{N}: \mathrm{P}: \mathrm{K}$, and (viii) $\mathrm{T}_{8}-75 \%$ BioF/liquid $+25 \% \mathrm{~N}: \mathrm{P}: \mathrm{K}$.
Application of $\mathrm{N}: \mathrm{P}: \mathrm{K}$ and Biofertilizer

The full dose of $\mathrm{P}$ and $\mathrm{K}$ were applied using TSP and MOP, respectively, at the time of final plot preparation. Nitrogen as urea was applied in three equal splits: final plot preparation, 30 and 60 days after transplanting. BioF/compost at the rate of $618 \mathrm{~g} / \mathrm{plot}$ was applied to the soil immediately before transplanting of the seedlings. In case of $\mathrm{BioF} /$ liquid, roots of the tomato seedlings were immersed and kept for $30 \mathrm{~min}$ in BioF/liquid. Residual BioF/liquid was also applied at the rate of $5 \mathrm{ml} /$ plant in each pit immediately after transplanting of seedlings.

\section{Data Collection}

Data were collected from five randomly selected plants from each plot in such a way that the border effect was avoided for high precision. The different parameters such as plant height, number of leaves and branches per plant, root and shoot dry matter (oven dried at $70{ }^{\circ} \mathrm{C}$ for 3 days) weight $(\mathrm{g})$ of plant were determined at $50 \%$ flowering stage, number of flower clusters per plant and number of flowers per cluster counted during pick flowering stage. Ripen tomatoes were harvested at 3-4 days interval, counted, and weighed. Yield data were converted from each plot in $\mathrm{t} / \mathrm{ha}$.

\section{Biochemical Analysis}

Protein content was quantified as the procedure described by Lowry et al. [22]. Sugar content was determined by the method described by Somogyi [32]. Ascorbic acid content was analyzed based on procedure described by Mukherjee and Choudhury [25]. Lycopene and $\beta$-carotene content was quantified by spectrophotometer (Model 200-20, Hitachi, Japan) according to Nagata et al. [26]. The extraction procedure adopted for calcium $(\mathrm{Ca})$ and magnesium $(\mathrm{Mg})$ was as described by Hunter [17]. Potassium (K) was extracted as per Jackson [19] and estimated by atomic absorption spectrophotometer. Phosphorus (P) was determined by the method described by Olsen et al. [27]. Aqua 
regia extraction method [11] followed by atomic absorption spectrophotometer were used for assessment of heavy metals (trace elements).

\section{Statistical Analysis}

Analysis of variance and comparison of means were calculated separately with statistical package MSTAT-C [24]. The means were compared by using the least significance difference (LSD) test. The significance of difference between the pairs of treatment means was evaluated by Duncan's multiple range test (DMRT) at $95 \%$ confidence levels $(P \leq 0.05)$.

\section{Results and Discussion}

\section{Vegetative Growth}

Vegetative growth, such as plant height, number of leaves and branches per plant was significantly influenced by the application of biofertilizer alone or in combination with $\mathrm{N}: \mathrm{P}: \mathrm{K}$ (Table 3). Treatments $\mathrm{T}_{2}, \mathrm{~T}_{4}$, and $\mathrm{T}_{7}$ offered significantly $(P \leq 0.05)$ higher plant height and number of leaves per plant. However, moderate plant height was recorded in treatments $T_{3}$ and $T_{8}$. The maximum number of branches per plant achieved by the standard dose of N:P:K $\left(\mathrm{T}_{2}\right)$ followed by the treatments $\mathrm{T}_{7}$ and $\mathrm{T}_{4}$. BioF/compost $\left(\mathrm{T}_{3}\right)$ produced significantly higher plant height, number of leaves and branches per plant as compared to the BioF/liquid $\left(\mathrm{T}_{6}\right)$. Furthermore, application of $50 \% \mathrm{BioF} /$ compost or $50 \%$ $\mathrm{BioF} /$ liquid combined with $50 \% \mathrm{~N}: \mathrm{P}: \mathrm{K}$ (i.e., treatments $\mathrm{T}_{4}$ and $\mathrm{T}_{7}$ ) enhanced significantly higher plant height, number of leaves and branches per plant over the treatments $T_{3}$ and
$\mathrm{T}_{6}$. The lowest plant height, number of leaves and branches per plant were recorded in treatments $\mathrm{T}_{1}$ and $\mathrm{T}_{6}$.

Enhanced growth response of several plants, such as bean [18], cucumber [20], maize [9], and tomato [28] were also noticed by the application of Trichoderma spp. and other biofertilizers [12,21]. The increased plant growth by Trichoderma (T. harzianum strain T22, T39, and A6) may be due to production of secondary metabolites which may act as an auxin-like compound [34, 35]. Secondary metabolites such as harzianolide, anthraquinoues, T39 butenolide isolated from Trichoderma spp. was shown to increase growth of wheat [35] while harzianic acid increased the growth of canola [36]. Conversely, at higher concentrations, several secondary metabolites inhibited the plant growth [35, 36]. It has been shown that Trichoderma spp. increased nutrient uptake through enhanced root growth or promoted availability of necessary nutrients leading to growth of the plants [15]. Moreover, Trichoderma reduced the concentrations of substances in soil that are inhibitory to plant growth $[20,38,40]$. It has also been reported that $T$. harzianum 1295-22 could improve nitrogen use efficiency and could solubilize a number of poorly soluble nutrients, such as $\mathrm{Mn}^{4+}, \mathrm{Fe}^{3+}$, and $\mathrm{Cu}^{2+}$, etc., leading to better plant growth and development [2]. Thus, one or several mechanisms may be involved in regulation of growth of tomato by Trichoderma-enriched biofertilizer alone or in combination with $\mathrm{N}: \mathrm{P}: \mathrm{K}$.

\section{Dry Matter Production}

Shoot and root dry matter weight (per plant) was significantly $(P \leq 0.05)$ influenced by combined application of biofertilizer and N:P:K (Table 3). Treatments $\mathrm{T}_{7}$ and $\mathrm{T}_{4}$ produced maximum root and shoot dry matter weight. The

Table 3 Impact of Trichoderma-enriched biofertilizer (BioF) on vegetative growth and dry matter production of tomato as sole and combination with N:P:K application at field condition

\begin{tabular}{|c|c|c|c|c|c|}
\hline \multirow[t]{2}{*}{ Treatments } & \multirow{2}{*}{$\begin{array}{l}\text { Plant } \\
\text { height }(\mathrm{cm})\end{array}$} & \multirow{2}{*}{$\begin{array}{l}\text { Number of } \\
\text { leaves/plant }\end{array}$} & \multirow{2}{*}{$\begin{array}{l}\text { Number of } \\
\text { branches/plant }\end{array}$} & \multicolumn{2}{|c|}{ Dry matter weight/plant $(\mathrm{g})$} \\
\hline & & & & Root & Shoot \\
\hline $\mathrm{T}_{1}$ (control, without BioF and NPK) & $66.33 \mathrm{c}$ & $34.60 \mathrm{f}$ & $6.33 \mathrm{e}$ & $2.87 \mathrm{e}$ & $30.55 \mathrm{e}$ \\
\hline $\mathrm{T}_{2}$ (standard dose of $\left.\mathrm{N}: \mathrm{P}: \mathrm{K}\right)^{\mathrm{a}}$ & $95.06 \mathrm{a}$ & $105.96 \mathrm{a}$ & $13.10 \mathrm{a}$ & $3.77 \mathrm{~d}$ & $83.31 \mathrm{~b}$ \\
\hline $\mathrm{T}_{3}(\mathrm{BioF} / \text { compost })^{\mathrm{b}}$ & $80.53 \mathrm{~b}$ & $53.40 \mathrm{e}$ & $8.20 \mathrm{de}$ & $3.90 \mathrm{~d}$ & $45.35 \mathrm{~d}$ \\
\hline $\mathrm{T}_{4}\left(50 \%\right.$ BioF/compost, i.e., $\mathrm{T}_{3}+50 \% \mathrm{~N}: \mathrm{P}: \mathrm{K}$, i.e., $\left.\mathrm{T}_{2}\right)$ & $93.80 \mathrm{a}$ & $104.50 \mathrm{a}$ & $11.20 \mathrm{abc}$ & $6.38 \mathrm{a}$ & $93.20 \mathrm{a}$ \\
\hline $\mathrm{T}_{5}\left(75 \%\right.$ BioF/compost, i.e., $\mathrm{T}_{3}+25 \% \mathrm{~N}: \mathrm{P}: \mathrm{K}$, i.e., $\left.\mathrm{T}_{2}\right)$ & $84.06 \mathrm{ab}$ & $76.66 \mathrm{~cd}$ & $9.26 \mathrm{~cd}$ & $4.67 \mathrm{c}$ & $83.54 \mathrm{~b}$ \\
\hline $\mathrm{T}_{6}(\mathrm{BioF} / \mathrm{liquid})^{\mathrm{c}}$ & $69.33 \mathrm{c}$ & $34.46 \mathrm{f}$ & $6.53 \mathrm{e}$ & $3.95 \mathrm{~d}$ & $42.05 \mathrm{~d}$ \\
\hline $\mathrm{T}_{7}\left(50 \%\right.$ BioF/liquid, i.e., $\mathrm{T}_{6}+50 \% \mathrm{~N}: \mathrm{P}: \mathrm{K}$, i.e., $\left.\mathrm{T}_{2}\right)$ & $95.06 \mathrm{a}$ & $106.10 \mathrm{a}$ & $12.26 \mathrm{ab}$ & $6.66 \mathrm{a}$ & $95.28 \mathrm{a}$ \\
\hline $\mathrm{T}_{8}\left(75 \%\right.$ BioF/liquid, i.e., $\mathrm{T}_{6}+25 \% \mathrm{~N}: \mathrm{P}: \mathrm{K}$, i.e., $\left.\mathrm{T}_{2}\right)$ & $82.60 \mathrm{~b}$ & $72.36 \mathrm{~d}$ & $10.30 \mathrm{bcd}$ & $5.08 \mathrm{bc}$ & $62.88 \mathrm{c}$ \\
\hline $\mathrm{CV}(\%)$ & 7.04 & 8.73 & 15.05 & 5.56 & 6.38 \\
\hline $\operatorname{LSD}(P \leq 0.05)$ & 10.27 & 10.61 & 2.54 & 0.44 & 7.33 \\
\hline
\end{tabular}

NB: [Different letters in column imply significant difference at $(P \leq 0.05),{ }^{a} 120: 108: 10 \mathrm{~kg} \mathrm{ha}^{-1}$ for N:P:K, ${ }^{\mathrm{b}}$ BioF/compost (composted kitchen wastes by $T$. harzianum T22), ${ }^{\mathrm{c}}$ BioF/liquid (Broth of spores suspension of $T$. harzianum T22)] 
Table 4 Efficacy of Trichoderma-enriched biofertilizer (BioF) on yield attributes of tomato grown in field condition

\begin{tabular}{|c|c|c|c|c|c|}
\hline Treatments & $\begin{array}{l}\text { Cluster } \\
\text { no/plant }\end{array}$ & $\begin{array}{l}\text { Flower } \\
\text { no/cluster }\end{array}$ & $\begin{array}{l}\text { Fruit } \\
\text { no/cluster }\end{array}$ & $\begin{array}{l}\text { Fruit } \\
\text { no/plant }\end{array}$ & $\begin{array}{l}\text { Individual } \\
\text { fruit wt. }(\mathrm{g})\end{array}$ \\
\hline $\mathrm{T}_{1}$ (control, without BioF and $\mathrm{N}: \mathrm{P}: \mathrm{K}$ ) & $2.60 \mathrm{~d}$ & $7.00 \mathrm{~d}$ & $2.06 \mathrm{~d}$ & $7.66 \mathrm{e}$ & $53.17 \mathrm{~b}$ \\
\hline $\mathrm{T}_{2}$ (standard dose of $\left.\mathrm{N}: \mathrm{P}: \mathrm{K}\right)^{\mathrm{a}}$ & $6.26 \mathrm{abc}$ & $8.82 \mathrm{ab}$ & $3.86 \mathrm{c}$ & $23.73 \mathrm{ab}$ & $67.43 \mathrm{a}$ \\
\hline $\mathrm{T}_{3}(\mathrm{BioF} / \text { compost })^{\mathrm{b}}$ & $6.20 \mathrm{abc}$ & $8.83 \mathrm{ab}$ & $3.80 \mathrm{c}$ & $19.20 \mathrm{~cd}$ & $64.52 \mathrm{a}$ \\
\hline $\mathrm{T}_{4}\left(50 \%\right.$ BioF/compost, i.e., $\mathrm{T}_{3}+50 \% \mathrm{~N}: \mathrm{P}: \mathrm{K}$, i.e., $\left.\mathrm{T}_{2}\right)$ & $6.93 \mathrm{ab}$ & $9.60 \mathrm{a}$ & $5.33 \mathrm{~b}$ & $24.86 \mathrm{a}$ & $72.00 \mathrm{a}$ \\
\hline $\mathrm{T}_{5}\left(75 \%\right.$ BioF/compost, i.e., $\mathrm{T}_{3}+25 \% \mathrm{~N}: \mathrm{P}: \mathrm{K}$, i.e., $\left.\mathrm{T}_{2}\right)$ & $5.80 \mathrm{bc}$ & $7.93 \mathrm{bcd}$ & $4.73 \mathrm{~b}$ & $21.76 \mathrm{bc}$ & $69.74 \mathrm{a}$ \\
\hline $\mathrm{T}_{6}(\mathrm{BioF} / \text { liquid })^{\mathrm{c}}$ & $3.40 \mathrm{~d}$ & $7.26 \mathrm{~d}$ & $2.13 \mathrm{~d}$ & $9.20 \mathrm{e}$ & $61.39 \mathrm{ab}$ \\
\hline $\mathrm{T}_{7}\left(50 \%\right.$ BioF/liquid, i.e., $\mathrm{T}_{6}+50 \% \mathrm{~N}: \mathrm{P}: \mathrm{K}$, i.e., $\left.\mathrm{T}_{2}\right)$ & $7.33 \mathrm{a}$ & $9.86 \mathrm{a}$ & $5.46 \mathrm{a}$ & $25.66 \mathrm{a}$ & $64.35 \mathrm{a}$ \\
\hline $\mathrm{T}_{8}\left(75 \%\right.$ BioF/liquid, i.e., $\mathrm{T}_{6}+25 \% \mathrm{~N}: \mathrm{P}: \mathrm{K}$, i.e., $\left.\mathrm{T}_{2}\right)$ & $5.23 \mathrm{c}$ & $7.50 \mathrm{~cd}$ & $4.53 \mathrm{~b}$ & $18.26 \mathrm{~d}$ & $62.01 \mathrm{ab}$ \\
\hline $\mathrm{CV}(\%)$ & 13.37 & 7.35 & 5.98 & 8.90 & 8.78 \\
\hline $\operatorname{LSD}(P \leq 0.05)$ & 1.28 & 1.07 & 0.41 & 2.93 & 9.89 \\
\hline
\end{tabular}

NB: [Different letters in column imply significant difference at $(P \leq 0.05),{ }^{a} 120: 108: 10 \mathrm{~kg} \mathrm{ha}^{-1}$ for N:P:K, ${ }^{\mathrm{b}}$ BioF/compost (composted kitchen wastes by $T$. harzianum T22), ${ }^{\mathrm{c}}$ BioF/liquid (Broth of spores suspension of $T$. harzianum T22)]

second highest root and shoot dry weight was found in treatments $\mathrm{T}_{8}$ and $\mathrm{T}_{2}$ and $\mathrm{T}_{5}$, respectively. However, the treatments $\mathrm{T}_{2}, \mathrm{~T}_{3}$, and $\mathrm{T}_{6}$ presented similar root dry matter weight. Like vegetative growth, the lowest root $(2.87 \mathrm{~g})$ and shoot $(30.55 \mathrm{~g})$ dry matter weight was recorded in control treatment $\left(\mathrm{T}_{1}\right)$. These results clearly illustrated that the dry matter of tomato plant was boosted by the combined use of biofertilizer and N:P:K. The increased root dry matter weight of plant could increase the chance for nutrients uptake through maximum exploitation of soils. The obtained results corroborate earlier findings [9] that the application of Trichoderma spp. increased both root and shoot growth of corn. Shoot and root dry matter weight of tomato was also increased by 120.6 and $78.6 \%$ when treated with other microbe, Rhodopseudomonas sp. [12].

\section{Yield Attributes}

Yield contributing characters of tomato was also significantly enhanced by Trichoderma-enriched biofertilizer and $\mathrm{N}: \mathrm{P}: \mathrm{K}$ application (Table 4). Number of clusters per plant (7.33) was significantly $(P \leq 0.05)$ higher in treatment $\mathrm{T}_{7}$ which was followed by the treatments $\mathrm{T}_{4}$ (6.93), $\mathrm{T}_{2}$ (6.26), and $\mathrm{T}_{3}(6.20)$. Similarly, the treatment $\mathrm{T}_{7}$ produced higher number of flowers per cluster (9.86), followed by the treatments $T_{3}(8.83)$ and $T_{2}(8.82)$. Both number of fruits per cluster and number of fruits per plant were maximum in treatments $T_{7}$ and $T_{4}$, there by indicating positive correlation between the two parameters. However, the lower number of clusters per plant, number of flowers and fruits per cluster, and number of fruits per plant was recorded in control $\left(\mathrm{T}_{1}\right)$ treatment that was statistically similar with treatment $\mathrm{T}_{6}$. Individual fruit weight was higher (64.35-67.43 g) in treatments $\mathrm{T}_{2}, \mathrm{~T}_{3}, \mathrm{~T}_{4}, \mathrm{~T}_{5}$, and $\mathrm{T}_{7}$ and lower $(53.17 \mathrm{~g})$ in control treatment. Thus, Trichoderma- enriched biofertilizer alone or in combination with chemical fertilizer may play an important role in the expression of yield-related traits of tomato. Vinale et al. [34] have also been reported that dramatic increase in the number of fruits per plant by application of Trichoderma spp. than the control in pepper, lettuce, and tomato grown in greenhouse.

\section{Yield of Tomato}

Yield per plant was found to be higher in treatment $T_{4}$ $(1.79 \mathrm{~kg})$, followed by the treatments $\mathrm{T}_{7}(1.65 \mathrm{~kg})$ and $\mathrm{T}_{2}$ $(1.60 \mathrm{~kg})$ cited in Table 5. The lowest yield per plant $(0.41 \mathrm{~kg})$ was obtained in control treatment $\left(\mathrm{T}_{1}\right)$ which was not significantly differed with treatment $\mathrm{T}_{6}$. Perhaps, supplemental nutrients are necessary for optimum proliferation and growth of microbes. In $\mathrm{T}_{6}$, it was absent; therefore, the yield of tomato was quite low. Conversely, in $\mathrm{T}_{3}$, nutrients were supplemented to the microbes by decomposed compost. In contrast to the control treatment, yield per plant was radically increased in all the treatments such as $\mathrm{T}_{2}, \mathrm{~T}_{3}, \mathrm{~T}_{4}, \mathrm{~T}_{5}$, $\mathrm{T}_{6}, \mathrm{~T}_{7}$, and $\mathrm{T}_{8}$ by $290.2,200.0,336.5,270.7,34.1,302.4$, and $182.0 \%$, respectively (Table 5). However, only the treatments $\mathrm{T}_{4}(11.87 \%)$ and $\mathrm{T}_{7}(3.13 \%)$ gave the superior yield over standard dose of N:P:K. The present result suggest that when nutrients were supplied from both the sources, i.e., biofertilizer and N:P:K, then the yield of tomato increased remarkably and significantly (even than the recommended dose of N:P:K) compared to sole application of biofertilizer. On the other hand, yield per plant over the standard dose of $\mathrm{N}: \mathrm{P}: \mathrm{K}$ was decreased by 5 and $27.5 \%$ at combined treatments of $\mathrm{T}_{5}$ and $\mathrm{T}_{8}$, respectively. Generally, $20 \%$ decrease in yield is expected in plants cultivated in organic systems than conventionally produced crops [30]. Thus, the treatments $T_{4}, T_{5}$, and $T_{7}$ may be recommended for organic or semi-organic tomato production. 
Table 5 Tomato yield status at field condition as influenced by Trichoderma-enriched biofertilizer (BioF) application

\begin{tabular}{|c|c|c|c|}
\hline \multirow[t]{2}{*}{ Treatment } & \multirow[t]{2}{*}{ Yield/plant $(\mathrm{kg})$} & \multicolumn{2}{|c|}{ Percent yield increased $(+) /$ decreased $(-)$} \\
\hline & & Over control & Over standard dose of $\mathrm{N}: \mathrm{P}: \mathrm{K}$ \\
\hline $\mathrm{T}_{1}$ (control, without BioF and N:P:K) & $0.41 \mathrm{~d}$ & - & $290.24(-)$ \\
\hline $\mathrm{T}_{2}$ (standard dose of $\left.\mathrm{N}: \mathrm{P}: \mathrm{K}\right)^{\mathrm{a}}$ & $1.60 \mathrm{ab}$ & $290.2(+)$ & - \\
\hline 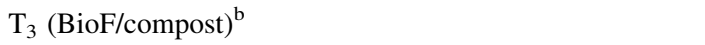 & $1.23 \mathrm{c}$ & $200.0(+)$ & $30.08(-)$ \\
\hline $\mathrm{T}_{4}\left(50 \%\right.$ BioF/compost, i.e., $\mathrm{T}_{3}+50 \%$ N:P:K, i.e., $\left.\mathrm{T}_{2}\right)$ & $1.79 \mathrm{a}$ & $336.5(+)$ & $11.87(+)$ \\
\hline $\mathrm{T}_{5}\left(75 \%\right.$ BioF/compost, i.e., $\mathrm{T}_{3}+25 \% \mathrm{~N}: \mathrm{P}: \mathrm{K}$, i.e., $\left.\mathrm{T}_{2}\right)$ & $1.52 \mathrm{~b}$ & $270.7(+)$ & $5.00(-)$ \\
\hline $\mathrm{T}_{6}(\mathrm{BioF} / \text { liquid })^{\mathrm{c}}$ & $0.55 \mathrm{~d}$ & $34.1(+)$ & $65.63(-)$ \\
\hline $\mathrm{T}_{7}\left(50 \%\right.$ BioF/liquid, i.e., $\mathrm{T}_{6}+50 \% \mathrm{~N}: \mathrm{P}: \mathrm{K}$, i.e., $\left.\mathrm{T}_{2}\right)$ & $1.65 \mathrm{ab}$ & $302.4(+)$ & $3.13(+)$ \\
\hline $\mathrm{T}_{8}\left(75 \%\right.$ BioF/liquid, i.e., $\mathrm{T}_{6}+25 \% \mathrm{~N}: \mathrm{P}: \mathrm{K}$, i.e., $\left.\mathrm{T}_{2}\right)$ & $1.16 \mathrm{c}$ & $182.0(+)$ & $27.50(-)$ \\
\hline $\mathrm{CV}(\%)$ & 11.42 & - & - \\
\hline $\operatorname{LSD}(P \leq 0.05)$ & 0.24 & - & - \\
\hline
\end{tabular}

NB: [Different letters in column imply significant difference at $(P \leq 0.05),{ }^{\mathrm{a}} 120: 108: 10 \mathrm{~kg} \mathrm{ha}^{-1}$ for N:P:K, ${ }^{\mathrm{b}}$ BioF/compost (composted kitchen wastes by $T$. harzianum T22), ${ }^{\mathrm{c}}$ BioF/liquid (Broth of spores suspension of $T$. harzianum T22)]

Nutritional Quality of Fruits

Tables 6 and 7 show the nutritional quality of tomato as affected by Trichoderma-enriched biofertilizer alone or in combination with N:P:K. Significantly the highest value of total soluble solids (TSS) was found in treatment $\mathrm{T}_{3}(\mathrm{BioF} /$ compost) but statistically similar reflections were also noted in treatments $\mathrm{T}_{2}, \mathrm{~T}_{4}, \mathrm{~T}_{7}$, and $\mathrm{T}_{8}$ (Table 6). It has been reported that application of increased doses of nitrogen enhances protein and reduces carbohydrate production [30]. Accordingly, similar profile of results of protein content was noticed in treatments $\mathrm{T}_{2}(100 \% \mathrm{~N}: \mathrm{P}: \mathrm{K}), \mathrm{T}_{4}$, and $\mathrm{T}_{7}$ of present studies. The higher sugar content $(5.11 \mathrm{mg} / 100 \mathrm{~g})$ was found in tomato fertilized with $\mathrm{BioF} /$ compost $\left(\mathrm{T}_{3}\right)$ followed by the treatments $\mathrm{T}_{4}, \mathrm{~T}_{6}, \mathrm{~T}_{7}$, and $\mathrm{T}_{8}$. Unlike TSS, protein and sugar content, the ascorbic acid content $(22.18 \mathrm{mg} / 100 \mathrm{~g})$ was higher in treatment $\mathrm{T}_{6}$ (BioF/liquid). However, the lower sugar and ascorbic acid content was obtained in treatment $\mathrm{T}_{2}$. Lycopene content was significantly higher in treatments $\mathrm{T}_{3}, \mathrm{~T}_{4}, \mathrm{~T}_{5}$, and $\mathrm{T}_{7}$, followed by the treatments of $T_{6}, T_{8}, T_{2}$, and $T_{1}$. Lycopene content of tomato fruits was reported to be higher when treated with biofertilizer, Rhodopseudomonas sp. than untreated control [21]. $\beta$-carotene content was also found higher in $\mathrm{T}_{3}$ treatment and the lowest $\beta$-carotene content detected in control treatment $\left(\mathrm{T}_{1}\right)$. The higher mineral content, such as $\mathrm{Ca}, \mathrm{Mg}, \mathrm{K}, \mathrm{Fe}, \mathrm{Zn}$ and $\mathrm{Cu}$ was found in tomato fertilized with $50 \%$ BioF/compost $+50 \% \mathrm{~N}: \mathrm{P}: \mathrm{K}$ ( $\mathrm{T}_{4}$ treatment) and the lowest value was recorded in control treatment. Manganese and phosphorus contents were obtained higher in treatment $\mathrm{T}_{3}$. These results suggested that biofertilizer alone or in combination with $\mathrm{N}: \mathrm{P}: \mathrm{K}$ may influence the nutritional quality of tomato.

Nutrient content of tomatoes are reported to be influenced by environmental factors and cultural practices. It is reported that organically grown crops contain more dry

Table 6 Outcome of Trichoderma-enriched biofertilizer (BioF) on biochemical properties of tomato fruits (per $100 \mathrm{~g}$ of tomato)

\begin{tabular}{|c|c|c|c|c|c|c|}
\hline Treatment & $\begin{array}{l}\text { Total } \\
\text { soluble solid }\end{array}$ & $\begin{array}{l}\text { Protein } \\
\text { content }(\mathrm{g})\end{array}$ & $\begin{array}{l}\text { Total } \\
\text { sugar }(g)\end{array}$ & $\begin{array}{l}\text { Ascorbic } \\
\text { acid (mg) }\end{array}$ & $\begin{array}{l}\beta \text {-carotene } \\
(\mathrm{mg})\end{array}$ & $\begin{array}{l}\text { Lycopene } \\
(\mathrm{mg})\end{array}$ \\
\hline $\mathrm{T}_{1}$ (control, without BioF and $\mathrm{N}: \mathrm{P}: \mathrm{K}$ ) & $6.43 \mathrm{~b}$ & $0.62 \mathrm{~cd}$ & $3.21 \mathrm{~d}$ & $12.32 \mathrm{de}$ & $0.074 \mathrm{~d}$ & $0.032 \mathrm{~d}$ \\
\hline $\mathrm{T}_{2}(\text { standard dose of } \mathrm{N}: \mathrm{P}: \mathrm{K})^{\mathrm{a}}$ & $6.97 \mathrm{a}$ & $0.81 \mathrm{a}$ & $2.73 \mathrm{e}$ & $7.87 \mathrm{f}$ & $0.087 \mathrm{c}$ & $0.054 \mathrm{c}$ \\
\hline $\mathrm{T}_{3}(\mathrm{BioF} / \text { compost })^{\mathrm{b}}$ & $7.13 \mathrm{a}$ & $0.71 \mathrm{~b}$ & $5.11 \mathrm{a}$ & $18.03 \mathrm{~b}$ & $0.106 \mathrm{a}$ & $0.096 \mathrm{a}$ \\
\hline $\mathrm{T}_{4}\left(50 \%\right.$ BioF/compost, i.e., $\mathrm{T}_{3}+50 \% \mathrm{~N}: \mathrm{P}: \mathrm{K}$, i.e., $\left.\mathrm{T}_{2}\right)$ & $6.93 \mathrm{a}$ & $0.84 \mathrm{a}$ & $3.77 \mathrm{~b}$ & $11.47 \mathrm{e}$ & $0.099 \mathrm{~b}$ & $0.105 \mathrm{a}$ \\
\hline $\mathrm{T}_{5}\left(75 \%\right.$ BioF/compost, i.e., $\mathrm{T}_{3}+25 \% \mathrm{~N}: \mathrm{P}: \mathrm{K}$, i.e., $\left.\mathrm{T}_{2}\right)$ & $6.50 \mathrm{~b}$ & $0.65 \mathrm{c}$ & $3.49 \mathrm{c}$ & $15.43 \mathrm{c}$ & $0.095 \mathrm{~b}$ & $0.095 \mathrm{a}$ \\
\hline $\mathrm{T}_{6}(\mathrm{BioF} / \mathrm{liquid})^{\mathrm{c}}$ & $6.17 \mathrm{c}$ & $0.58 \mathrm{~d}$ & $3.69 \mathrm{~b}$ & $22.18 \mathrm{a}$ & $0.085 \mathrm{c}$ & $0.076 \mathrm{~b}$ \\
\hline $\mathrm{T}_{7}\left(50 \%\right.$ BioF/liquid, i.e., $\mathrm{T}_{6}+50 \% \mathrm{~N}: \mathrm{P}: \mathrm{K}$, i.e., $\left.\mathrm{T}_{2}\right)$ & $7.06 \mathrm{a}$ & 0.81 a & $3.85 \mathrm{~b}$ & $13.59 \mathrm{~d}$ & $0.095 \mathrm{~b}$ & $0.105 \mathrm{a}$ \\
\hline $\mathrm{T}_{8}\left(75 \%\right.$ BioF/liquid, i.e., $\mathrm{T}_{6}+25 \% \mathrm{~N}: \mathrm{P}: \mathrm{K}$, i.e., $\left.\mathrm{T}_{2}\right)$ & $7.03 \mathrm{a}$ & $0.59 \mathrm{~cd}$ & $3.76 \mathrm{~b}$ & $\mathrm{~s}$ & $0.094 \mathrm{~b}$ & $0.059 \mathrm{bc}$ \\
\hline $\mathrm{CV}(\%)$ & 2.02 & 4.59 & 2.66 & 6.99 & 2.52 & 4.73 \\
\hline $\operatorname{LSD}(P \leq 0.05)$ & 0.24 & 0.054 & 0.17 & 1.79 & 0.005 & 0.017 \\
\hline
\end{tabular}

NB: [Different letters in column imply significant difference at $(P \leq 0.05),{ }^{a} 120: 108: 10 \mathrm{~kg} \mathrm{ha}^{-1}$ for N:P:K, ${ }^{\mathrm{b}}$ BioF/compost (composted kitchen wastes by $T$. harzianum T22), ${ }^{\mathrm{c}}$ BioF/liquid (Broth of spores suspension of T. harzianum T22)] 


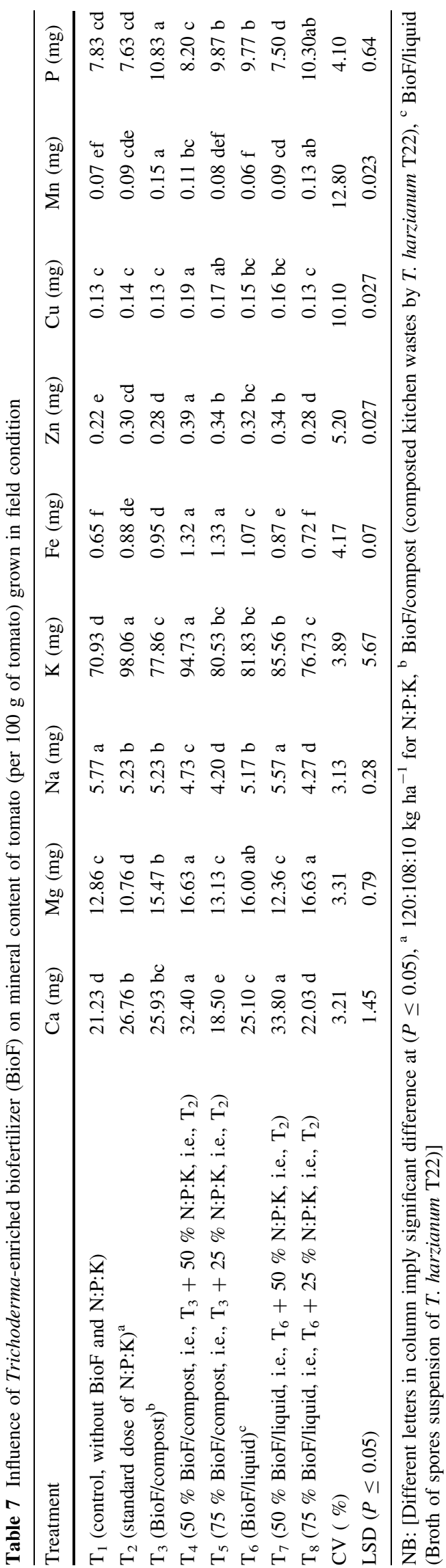

matter, total sugar, vitamin $\mathrm{C}$, essential amino acids, phenolic compounds, and minerals such as iron, magnesium, calcium, manganese, copper, potassium, sodium, and zinc than the non-organic crops [7, 13, 41]. It has also been reported that organic fertilizer is superior to conventional synthetic fertilizer in achieving more nutritious fruits or vegetables [3]. In this study, nutrient content was found to be higher in plants fertilized with biofertilizer alone or in combination with inorganic fertilizer compared to the recommended dose of $\mathrm{N}: \mathrm{P}: \mathrm{K}$ only (Tables 6,7 ). Thus, biofertilizer alone or combined with chemical fertilizer may be recommended for higher yield and higher nutritional quality of tomato. Biofertilizer along with chemical fertilizer may save at least $50 \% \mathrm{~N}: \mathrm{P}: \mathrm{K}$ fertilizer and may reduce the environmental pollution too. Nevertheless, biofertilizer may be used for organic tomato production, which is becoming increasingly popular worldwide.

\section{Conclusions}

In this study, Trichoderma-enriched biofertilizer played significant role in both yield and quality improvement of tomato. Combined application of biofertilizer and chemical fertilizer (especially $50 \% \mathrm{BioF}+50 \% \mathrm{~N}: \mathrm{P}: \mathrm{K}$ ) enhanced vegetative and reproductive growth, yield and nutritional quality of tomato by slow and steady release of nutrients to the plants than the sole application of $\mathrm{N}: \mathrm{P}: \mathrm{K}$ fertilizer. The present findings, i.e., Trichoderma-enriched biofertilizer application could save at least $50 \%$ N:P:K, i.e., urea:TSP:MOP can reduce cultivation cost of tomato while minimizing pollution by excessive use of $\mathrm{N}$ fertilizer.

Acknowledgments The authors are grateful and express their sincere thanks to Research Management Centre (RMC), Bangabandhu Sheikh Mujibur Rahman Agricultural University (BSMRAU), Gazipur, Bangladesh for extending cooperation and assistance for conducting this study by providing financial support.

\section{References}

1. Alfano G, Ivey MLL, Cakir C, Bos JIB, Miller SA, Madden LV, Kamoun S, Hoitink HAJ (2007) Systemic modulation of gene expression in tomato by Trichoderma hamatum 382. Phytopathol 97:429-437

2. Altomare C, Norvell WA, Bjorkman T, Harman GB (1999) Solubilization of phosphates and micronutrients by the plantgrowth-promoting and biocontrol fungus Trichoderma harzianum Rifai 1295-22. Appl Environ Microbiol 65:2926-2933

3. Asami DK, Hong YH, Barret DM, Mitchel AE (2003) A comparison of the total phenolic and ascorbic acid contents of freezedried and air-dried marionberry, strawberry and corn grown using conventional, organic and sustainable agricultural practices. J Agric Food Chem 51:1237-1241

4. Bal U, Altintas S (2006) A positive side effect from Trichoderma harzianum, the biological control agent: increased yield in vegetable crops. J Environ Protect Ecol 7:383-387 
5. Bal U, Altintas S (2008) Effects of Trichoderma harzianum on lettuce in protected cultivation. J Cent Eur Agric 1:63-70

6. BARC (Bangladesh Agricultural Research Council) (2005) Fertilizer recommendation guide-2005. Soils publication no. 45 . Bangladesh Agricultural Research Council, Dhaka

7. Barrett DM, Weakley C, Diaz JV, Watnik M (2007) Quality and nutritional differences in processing tomatoes grown under commercial organic and conventional systems. J Food Sci 72: $441-450$

8. Benítez T, Rincón AM, Limón MC, Codón AC (2004) Biocontrol mechanisms of Trichoderma strains. Intl Microbiol 7:249-260

9. Björkman T, Price HC, Harman GE, Ballerstein J, Nielsen P (1994) Improved performance of shrunken 2 sweet corn using Trichoderma harzianum as a bioprotectant. Hort Sci 29:471

10. Chang Y-C, Chang Y-C, Baker R, Kleifeld O, Chet I (1986) Increased growth of plants in presence of the biological control agent Trichoderma harzianum. Plant Dis 70:145-148

11. Cottonie A, Velghe G, Verloo M, Kiekens L (1979) Analytical methods for plants and soils. Laboratory of Analytical and Agrochemistry, State University, Ghent, p 29

12. Datta JK, Banerjee A, Saha Sikdar M, Gupta S, Mondal NK (2009) Impact of combined exposure of chemical fertilizer, biofertilizer and compost on growth, physiology and productivity of Brassica campestries in old alluvial soil. J Environ Biol 30: 797-800

13. Dumas Y, Dadomo M, Di Lucca G, Grolier P (2003) Effects of environmental factors and agricultural techniques on antioxidant content of tomatoes. J Sci Food Agric 83:369-382

14. Harman GE (2006) Overview of mechanisms and uses of Trichoderma spp. Phytopathol 96:190-194

15. Harman GE, Howell CR, Viterbo A, Chet I, Lorito M (2004) Trichoderma species-opportunistic, avirulent plant symbionts. Nat Rev Microbiol 2:43-56

16. Heeb A, Lundegårdh B, Savage G, Ericsson T (2006) Impact of organic and inorganic fertilizers on yield, taste, and nutritional quality of tomatoes. J Plant Nutr Soil Sci 169:535-541

17. Hunter AH (1984) Soil fertility analytical services in Bangladesh. Consultancy report: Bangladesh Agricultural Research Project Phase II. BARC, Dhaka

18. Inbar J, Abramsky M, Cohen D, Chet I (1994) Plant growth enhancement and disease control by Trichoderma harzianum in vegetable seedlings grown under commercial conditions. Eur $\mathbf{J}$ Plant Pathol 100:337-346

19. Jackson ML (1973) Soil chemical analysis. Prentice Hall of India Pvt. Ltd, New Delhi

20. Kleifeld O, Chet I (1992) Trichoderma harzianum-interaction with plants and effect on growth response. Plant Soil 144: 267-272

21. Lee K-H, Koh R-H, Song H-G (2008) Enhancement of growth and yield of tomato by Rhodopseudomonas sp. under greenhouse condition. J Microbiol 6:641-646

22. Lowry OH, Brough NJR, Fan AL, Randal RJ (1951) Protein measurement with the Folin phenol reagent. J Biol Chem 193: 265-275

23. Marra R, Ambrosino P, Carbone V, Vinale F, Woo SI, Ruocco M, Ciliento R, Lanzuise S, Ferraioli S, Soriente I, Gigante S, Turrá D, Fogliano V, Scala F, Lorito M (2006) Study of the three-way interaction between Trichoderma atroviride, plant and fungal pathogens by using a proteomic approach. Curr Genet 50: 307-321

24. MSU (Michigan State University) (1989) The user's guide to MSTAT-C. Michigan State University, Lansing, MI

25. Mukherjee SP, Choudhury MA (1983) Implications of water stress induced changes in the levels of endogenous ascorbic acid and hydrogen peroxide in Vigna seedlings. Physiol Plant 58: 166-170

26. Nagata M, Dan K, Yamashita I (1992) Simple method of simultaneous determination of chlorophyll and carotenoids in tomato. J Jpn Soc Hort Sci 61:686-687

27. Olsen SR, Cole CV, Watanabe FS, Dean LA (1954) Estimation of available phosphorus in soils by extraction with sodium bicarbonate. USDA Cir. No. 939. USDA, Washington, DC, pp 171-179

28. Ozbay N, Newman SE, Brown WM (2004) The effect of the Trichoderma strains on the growth of tomato seedlings. Acta Hort 635:131-135

29. Reino JL, Guerrero RF, Hernández-Galán R, Collado IG (2008) Secondary metabolites from species of the biocontrol agent Trichoderma. Phytochem Rev 7:89-123

30. Rembiałkowska E (2007) Quality of plant products from organic agriculture. J Sci Food Agric 87:2757-2762

31. Shoresh M, Harman GE (2008) The molecular basis of shoot responses of maize seedlings to Trichoderma harzianum T22 inoculation of the root: a proteomic approach. Plant Physiol 147: $2147-2163$

32. Somogyi M (1952) Notes on sugar determination. J Biol Chem 195:19-23

33. Taiwo LB, Abediran JA, Sonubi OA (2007) Yield and quality of tomato grown with organic and synthetic fertilizers. Int J Veg Sci 13:5-19

34. Vinale F, Sivasithamparam K, Ghisalberti EL, Marra R, Woo SL, Lorito M (2008) Trichoderma-plant-pathogen interactions. Soil Biol Biochem 40:1-10

35. Vinale F, Sivasithamparam K, Ghisalberti EL, Marra R, Barbetti MJ, Li H, Woo SL, Lorito M (2008) A novel role for Trichoderma secondary metabolites in the interactions with plants. Physiol Mol Plant Pathol 72:80-86

36. Vinale F, Flematti G, Sivasithamparam K, Lorito M, Marra R, Skelton BW, Ghisalberti EL (2009) Harzianic acid, an antifungal and plant growth promoting metabolite from Trichoderma harzianum. J Nat Prod 72:2032-2035

37. Vinale F, Ghisalberti EL, Sivasithamparam K, Marra R, Ritieni A, Ferracane R, Woo SL, Lorito M (2009) Factors affecting the production of Trichoderma harzianum secondary metabolites during the interaction with plant pathogens. Lett Appl Microbiol 48:705-711

38. Wang C, Knill E, Glick BR, Defago G (2000) Effect of transferring 1-aminocyclopropane-1-carboxylic acid (ACC) deaminase genes into Pseudomonas fluorescens strain CHA0 and its gacA derivative CHA96 on their growth-promoting and diseasesuppressive capacities. Can J Microbiol 46:898-907

39. Wani SP, Lee KK (1995) Microorganisms as biological inputs for sustainable agriculture. In: Thampan PK (ed) Organic agriculture theory and practices. Tree Crops Development Foundation, Cochin

40. Windham MT, Elad Y, Baker R (1986) Mechanism for increased plant growth induced by Trichoderma spp. Phytopathol 76: $518-521$

41. Worthington V (2001) Nutritional quality of organic versus conventional fruits, vegetables, and grains. J Altern Complement Med 7:161-173

42. Yedidia I, Benharmou N, Chet I (1999) Induction of defense responses in cucumber plants (Cucumis sativas L.) by the biocontrol agent Trichoderma harzianum. Appl Environ Microbiol 65:1061-1070

43. Yedidia I, Srivastva AK, Kapulnik Y, Chet I (2001) Effects of Trichoderma harzianum on microelement concentrations and increased growth of cucumber plants. Plant Soil 235:235-242 